\title{
WHY IS GROWTH BETTER IN THE UNITED STATES THAN IN OTHER INDUSTRIAL COUNTRIES
}

\author{
Martin S. Feldstein \\ Working Paper 23221 \\ http://www.nber.org/papers/w23221 \\ NATIONAL BUREAU OF ECONOMIC RESEARCH \\ 1050 Massachusetts Avenue \\ Cambridge, MA 02138 \\ March 2017
}

This paper was presented at the meeting of the Allied Social Sciences Association meeting in Chicago, January 7, 2017. The views expressed herein are those of the author and do not necessarily reflect the views of the National Bureau of Economic Research.

NBER working papers are circulated for discussion and comment purposes. They have not been peer-reviewed or been subject to the review by the NBER Board of Directors that accompanies official NBER publications.

(C) 2017 by Martin S. Feldstein. All rights reserved. Short sections of text, not to exceed two paragraphs, may be quoted without explicit permission provided that full credit, including ()$^{\circ}$ notice, is given to the source. 
Why is Growth better in the United States than in other Industrial Countries

Martin S. Feldstein

NBER Working Paper No. 23221

March 2017

JEL No. E6,E60

\section{ABSTRACT}

Although the official statistics imply that the rate of growth of real GDP in the United States has declined in recent years, it has still been substantially higher than the real growth rates in Europe and the other industrial countries, leading to higher real per capita incomes. This paper discusses ten reasons for the higher rate of real economic growth.

Martin S. Feldstein

President Emeritus

NBER

1050 Massachusetts Avenue

Cambridge, MA 02138-5398

and NBER

msfeldst@nber.org 
Why is Growth Better in the United States than in other Industrial Countries? Martin Feldstein ${ }^{1}$

Although the official statistics imply that the rate of growth of real GDP in the United States has declined in recent years, it has still been substantially higher than the real growth rates in Europe and the other industrial countries. The sustained higher rate of real GDP growth in the United States over a longer period of time has resulted in a substantially higher level of real GDP per capita in the United States than in other major industrial countries.

In 2015 , real GDP per capita was $\$ 56,000$ in the United States. On a purchasing power basis, the real GDP per capita in that same year was only $\$ 47,000$ in Germany, $\$ 41,000$ in France and the United Kingdom, and just $\$ 36,000$ in Italy. So the official measures of real GDP clearly point to the cumulative result of higher sustained real growth rates in the United States than in the major industrial countries of Europe and Asia. ${ }^{2}$

${ }^{1}$ Professor of Economics, Harvard University. This paper was presented at the meeting of the Allied Social Sciences Association meeting in Chicago, January 7 , 2017.

2 In my remarks I will focus on the long-term differences in growth rates that have produced the current differences in the level of real GDP rather than the growth rate differences in the past few years. I don't understand why the measured rates of U.S. real GDP growth declined in the recent past or whether this was more than a return to the lower growth rates that prevailed in earlier years. 


\section{Real Growth is Higher than the Official Record Implies}

Before giving some reasons for the higher cumulative growth in the United States, I want to stress my belief that the official estimates of real GDP growth in the United States and probably in other industrial countries substantially understate the true rise in the real output of the economy. I have reached this conclusion by studying carefully the methods used by the U.S. Bureau of Labor Statistics (BLS) and the Bureau of Economic Analysis (BEA) to estimate real GDP growth. ${ }^{3}$

There are two reasons why the government statisticians in these agencies have a very difficult job in going from the annual rise in nominal GDP to the corresponding rise in real GDP and, as a result, produce estimates that understate the true rise in real GDP.

First, measuring the increase in real GDP requires taking into account the changes that occur in the quality of goods and services. Second, the measure of increased real output should in principle take into account the value to consumers of newly created goods and services. In practice, the government agencies underestimate the value of product improvements and do not even try to take into account the value to consumers that occurs when new products are created.

\footnotetext{
${ }^{3}$ These comments about the mismeasurement of real GDP growth are a summary of remarks that I made at the Brookings Institution on September $9^{\text {th }}$, 2016 (available at www.nber.org/feldstein) and of a longer technical discussion that will appear this year in the Journal of Economic Perspectives.
} 
Let me explain each of these in turn.

To assess changes in product quality, the BLS asks the manufacturers of a large number of products: “Did your product change from last year?” If the manufacturer says that the product did not change, any change in the price of the product is correctly treated as pure inflation. But if the manufacturer says the product did change, the BLS asks "What is the marginal cost of the new input requirements that are directly tied to changes in product quality?" If the manufacturer says there wasn't any increased cost, the BLS concludes that there's been no quality change.

In short, the BLS concludes that there has been a quality improvement if and only if there is an increase in the cost of making the product. That's a very narrow, and in my judgment, incorrect way to measure quality change. It says: "If it doesn't cost more to make the product, there's no quality improvement." In reality, of course, producers improve products in ways that don't cost more to produce or may even cost less. And that's what we, as economists , think of as true technical progress. But the official government method, which the BLS calls "the resource cost method of quality adjustment," focuses on the increased cost of inputs rather than the value of the product to consumers and other end users.

Although this is the dominant method used by the BLS, it is not the only method. For some products, the BLS uses hedonic regressions to assess the relation 
between changes in the market price of a product and changes in a selected number of product attributes.

But the overall result of the official method is to understate the value of changes from year to year in product quality.

When new products are introduced, there is no attempt to reflect the extra value to consumers created by those products. When a new product is developed and sold to the public, its market value enters into nominal GDP. These nominal values of GDP are converted to real values using price indices that don't reflect the new product at all. Why? Because the new product is too small in the beginning to be worth changing the weights in the GDP price index. But over time, if the new product eventually represents a large enough amount of spending, the BLS includes the changes in its price explicitly in the price index. After that the BLS tracks increases and decreases in the price of the product like any other existing product. But the process that I've described never tries to take into account the value created by the new product per se. And that's true for smart phones, it's true for tablets, it's true for new pharmaceutical products, it's true for many, many other products.

Think about statins, the remarkable drug that lowers cholesterol and reduces deaths from heart attacks. By 2003, statins were the best-selling pharmaceutical product in history. By then it was in the price index. And when patents expired and generic forms of the statins became available, the prices fell and the BLS recorded 
that, implying a rise in real incomes. But it never estimated anything for the value that consumers would place on the major reduction in mortality that came about as a result of the introduction of statins.

A quick history of statins indicates the importance of ignoring the value to consumers when this new product was created. In 1994 researchers published a five-year study of 4000-plus patients. They found that taking a statin drug caused a 35 percent reduction in cholesterol and a 42 percent reduction in the probability of dying of a heart attack. Well, it didn't take long for statins to become a best-selling product with dramatic effects on cholesterol and on heart attacks. Between 2000 and 2007 the percentage of men 65 and older taking a statin doubled to about 50 percent. High cholesterol levels declined by more than half among men and women over age 75, and the death rate from heart disease among those over 65 fell by one third.

This was a remarkable contribution to the public's well-being over a relatively short number of years, and yet this part of the contribution of the new product was not reflected in real output or real growth of GDP. And this of course is just one example of a myriad of new goods and services that get introduced year after year.

According to the official statistics, real GDP per capita increased at an annual rate of only 1.4 percent in the most recent twenty year period. I don't know by how 
much these official estimates understate the true rise in real GDP per capita. It could easily be by two percent a year, implying that the true rise in real GDP was more than twice as fast as the official estimates.

I have not studied the methods used by the statistical agencies of other governments in the same detail but my impression is that their methods are very similar. This conclusion is supported by the methods advocated by the International Monetary Fund.

Any attempt to compare the growth rates of real GDP among industrial countries using the official statistics implicitly assumes that the extent of underestimation is similar among all of those countries. So that caveat should be born in mind in comparing the U.S. growth rate with the growth rates of other countries.

\section{Ten Reasons for High Growth in the United States}

When I consider the features of the American economy that contribute to its stronger sustained rate of economic growth, I can think of ten different features that distinguish the United States from other industrial economies. Of course, not all of these features are present to a greater extent in the United States than in all other industrial countries. Moreover, I will only list and describe these features but cannot rank them in order of their importance. And I believe that these features interact in 
contributing to stronger growth and are not merely additive. But for what it is worth, here is my list of ten pro-growth features of the U.S. economy.

(1) An entrepreneurial culture. Individuals in the United States demonstrate a desire to start businesses and grow them and a willingness to take risks. There is no penalty in the U.S. culture for failure and for starting again. Even students who have gone to college or to a business school show this entrepreneurial desire. The successes in silicon valley and with such firms as Facebook inspire entrepreneurial activities.

(2) A financial system that supports entrepreneurial activities. The United States has a more developed system of equity finance than the countries of Europe and a decenetralized banking system that helps local entrepreneurs. The equity finance system includes "angel investors" willing to finance start-up firms and a very active venture capital market that helps finance the growth of firms. The national system of small local banks that provide loans to new businesses includes more than 7,000 individual small banks that are important in their local communities.

(3) World class research universities. These produce much of the basic research that drives the high-tech entrepreneurial activities. Faculty members and doctoral graduates often spend time in new businesses that are located near these universities. The culture of the universities and of the businesses welcomes these overlapping activities between academia and the private sector. The great research 
universities attract talented students from around the world, many of whom end up remaining in the United States.

(4) Labor markets that generally link workers and jobs unimpeded by large trade unions, state-owned enterprises, or excessively restrictive labor regulations. In the private sector, less than seven percent of the labor force is unionized. There are virtually no state-owned enterprises. While labor laws and regulations affect working conditions and hiring rules, they are much less onerous than in Europe. State level licensing rules are the probably the most serious barrier to job changing and to interstate mobility.

(5) A growing population, reflecting both natural growth and immigration. The growing population means a younger and therefore more flexible and trainable workforce. A high degree of geographic mobility within the United States increases the effectiveness of the labor force. The higher level of real income makes the United States an attractive destination for ambitious and talented young people around the world. Although there are restrictions on immigration to the United States, there are also special rules that provide access to the U.S. economy and a path for citizenship ("green cards") based on individual talent and industrial sponsorship. A separate special "green card lottery" provides a way for eager people to come to the United States. 
(6) A culture and a tax-transfer system that encourages hard work and long hours. The average employee in the United States works 1800 hours per year, substantially longer than the 1500 hours worked in France and the 1400 hours worked in Germany. Of course workers in some Asian countries work much longer hours, with working hours over 2200 per year in Hong Kong, Singapore, and Korea.

(7) A supply of energy that makes North America energy independent. The private ownership of land and mineral rights has facilitated a rapid development of fracking to expand the supply of oil and gas.

(8) A favorable regulatory environment. Although the system of government regulations needs improvement, it is less burdensome on businesses than the regulations imposed by European countries and the European Union.

(9) A smaller size of government than in other industrial countries. According to the OECD, outlays of the U.S. government at the federal, state and local levels totaled 38 percent of GDP while the corresponding figure was 44 percent in Germany, 51 percent in Italy and 57 percent in France. The higher level of government spending in other countries implies that not only is a higher share of income taken in taxes but also that there are higher transfer payments that reduce incentives to work.

In the United States, the highest marginal tax rate on wage income and entrepreneurial profits is 40 percent and, for married taxpayers, only applies to 
incomes over $\$ 466,000$. The 33 percent tax rate only applies to married taxpayers with incomes over $\$ 231,000$. There is a payroll tax of 15.3 percent but it only applies to incomes up to $\$ 127,200$. There is no value added tax. State income taxes vary but are generally about five percent and are deductible by high income taxpayers in calculating their taxable incomes. So Americans have a higher pre-tax reward to working and can keep a larger share of their earnings.

(10) The U.S. has a decentralized political system in which states compete. The competition among states encourages entrepreneurship and work effort and the legal systems protect the rights of property owners and entrepreneurs. The United States political system assigns many legal rules and taxing power to the fifty individual states. The states then compete for businesses and for individual residents by their legal rules and tax regimes. Some states have no income taxes and have labor laws that limit unionization. States provide high quality universities with low tuition for in-state students. They compete also in their legal liability rules. The legal systems attract both new entrepreneurs and large corporations. The United States is perhaps unique among high-income nations in the degree of decentralization.

\section{Schumpeter's Warning}

The specific institutions and rules that I have described reflect the more general intellectual and political climate of the country. Although there is a wide range of political and ideological opinion in the United States, the center of gravity of 
American political opinion is much more "liberal" (in the European sense) than it is in Europe, i.e., much more market-oriented and supportive of private ownership, free enterprise, small business, etc.. Four of the six presidents since 1980 have been Republicans, both houses of Congress now have Republican majorities, and the governors of two thirds of the states are Republicans. Although the government provides means tested benefits for health care (Medicaid) and for food consumption (the food stamp program), these programs are much more limited than in Europe.

In his 1942 book, Socialism, Capitalism and Democracy, Joseph Schumpeter warned that capitalism would decline and fail because the political and intellectual environment needed for capitalism to flourish would be undermined by the success of capitalism and by the critique of intellectuals. He argued that popularly elected social democratic parties would create a welfare state that would restrict entrepreneurship.

Although Schumpeter's book was published more than twenty years after he had moved from Europe to the United States, his warning seems more appropriate to Europe today than to the United States. The welfare state has grown in the United States, but much less than it has grown in Europe. And the intellectual climate in the United States is much more supportive of capitalism.

If Schumpeter were with us today, he might point to the growth of the social democratic parties in Europe and the resulting expansion of the welfare state as 
reasons why the industrial countries of Europe have not enjoyed the same robust economic growth that has prevailed in the United States.

Cambridge, MA 